\title{
Rain, dew, and humid air as drivers of morphology, function and spatial distribution in epiphytic lichens
}

\author{
Yngvar GAUSLAA
}

\begin{abstract}
This review is a first attempt to combine and compare spatial distribution of the three main water sources, rain, dew and humid air, with water-related traits of mainly epiphytic macrolichens in a conceptual and functional model. By comparing climatic and lichenological knowledge, various effects of dewfall, rainfall and humid air on epiphytic lichen morphology and function are analyzed to search for traits and patterns. Although dew, rain and humid air cause lichen hydration and activate photosynthesis, these atmospheric hydration sources influence and shape lichens differently. In order to visualize hydration patterns, dew, rain and humid air are shown as corners in a triangle exhibiting the various combinations of these hydration sources. The sources of hydration vary on temporal scales, and on the spatial scales: regional, landscape, stand and tree. Lichen growth form, photobiont type, water-holding capacity (WHC) and suprasaturation depression show clear patterns within the hydration triangle. For most lichen species, one average pre-dawn dewfall approximately fills their average internal WHC. This suggests that lichens are optimally designed to utilize dew rather than rain, consistent with literature emphasizing dew as a driver for annual C-assimilation in chlorolichens. However, rain is needed to fill their external WHC and to fully hydrate most cyanolichens. Including the sources of hydration and internal lichen variables, such as water-holding capacity, will improve modelling of local and global future scenarios on lichen distribution and biomass production.
\end{abstract}

Key words: alectorioid lichens, functional groups, humidity, hydration, lichen morphology, review, water-holding capacity

\section{Introduction}

Lichens are used as indicators of environmental factors such as toxic pollutants (Cislaghi \& Nimis 1997; Brunialti \& Frati 2007), acid rain (Gauslaa 1995; Purvis et al. 2008), nitrogen deposition (van Herk et al. 2003; Frati et al. 2008; Hauck 2010; Johansson et al. 2010), ecological continuity in forest ecosystems (Rose 1976; McCune et al. 2000; Bolliger et al. 2007; Fritz et al. 2008), forest edge microclimate (Renhorn et al. 1997; Esseen \& Renhorn 1998; Coxson \& Stevenson 2007b) and climate change (Cornelissen et al. 2001; Walker et al. 2006; Lang et al. 2009). With their poikilohydric way of life, lichens also

Y. Gauslaa: Department of Ecology and Natural Resource Management, Norwegian University of Life Sciences, P. O. Box 5003, NO-1432 Ås, Norway.

Email: yngvar.gauslaa@umb.no tell stories about spatial and temporal variation in hydration sources. Because many epiphytic lichens, macrolichens in particular, are exposed to ambient air with large area/ biomass-ratios, they likely rank among the more responsive organisms to humidity. For example, two similar spruce canopies in one single valley with relatively low rainfall can host totally different epiphytic communities; the one exposed to atmospheric hydration sources only is heavily loaded with pendulous hair lichens (Fig. 1A), and the other, additionally influenced by liquid water from the spray zone of a waterfall, is loaded with foliose lichens (Fig. 1B). Many lichen species with broad distribution ranges seem to respond more strongly to humidity factors than to temperature. For example, Jørgensen (1996) showed that $c$. 50 oceanic lichen species occurring in Norway have their main 

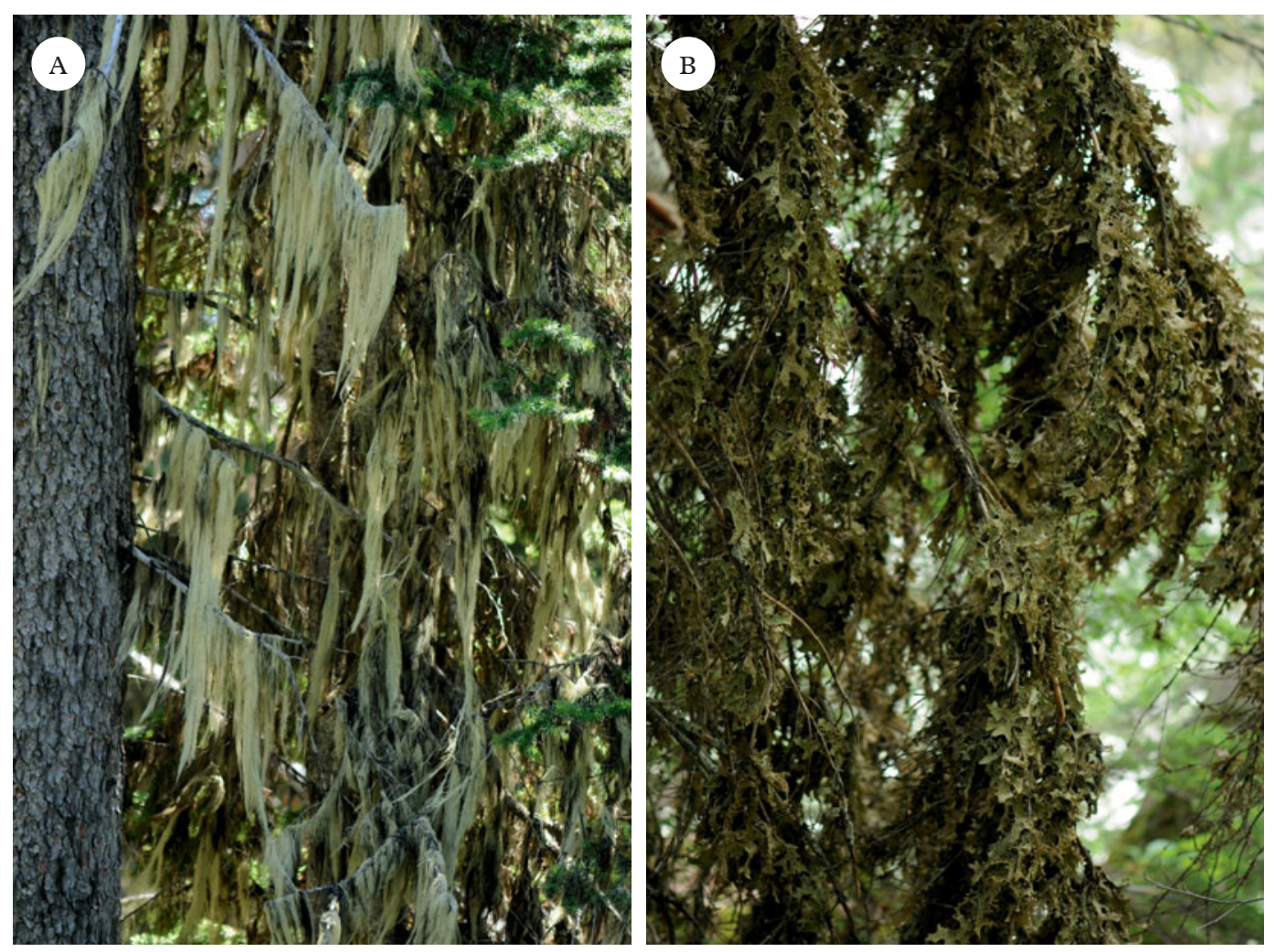

FIG. 1. The lower parts of two spruce (Picea engelmannii $x$ glauca) canopies located in the Clearwater valley, southern inland British Columbia. A, a tree in the upper-elevation forests (altitude $1800 \mathrm{~m}$ ) of the Trophy Mountains with dense cover of Alectoria sarmentosa and various Bryoria spp., but without cephalo- or cyanolichens; B, a tree along the Murtle River within the outer spray zone of Dawson Falls (altitude $800 \mathrm{~m}$ ), influenced by liquid water from the spray zone. This locality has a strong dominance of the cephalolichen Lobaria pulmonaria, with minor occurrences of cyanolichens such as L. hallii, L. scrobiculata, Pseudocyphellaria anomala, Leptogium spp. and Collema spp. Photographs: Y. Gauslaa. In colour online.

distribution area in tropical/subtropical rainforests, this notwithstanding that some of them extend northwards to boreal rainforests at the arctic circle.

Recent efforts to model lichen distributions (Ellis et al. 2007a, b; Braidwood \& Ellis 2012), as well as lichen growth (Eaton $\&$ Ellis 2012), by means of climatic variables have shown that climate matters, although such models consider rainfall as the only humidity parameter. Internal lichen parameters such as photobiont type (Lange \& Kilian 1985), water-holding capacity (Green \& Lange 1991; Gauslaa \& Solhaug 1998), growth form (Kershaw 1985), hydrophobicity of lichen surfaces (Lakatos et al. 2006) and presence/ absence of cortex (Pardow et al. 2010) also greatly influence moisture relations in lichens. For example, gel lichens such as the cyanobacterial Collema spp. accumulate considerable quanbities of water that keep the thallus hydrated for long periods (Galun 1963; Lange et al. 1998; Lange 2000). It is well known that the lichen water-holding capacity, which depends on morphological adaptation as well as on acclimation (Kershaw 1985; Gauslaa \& Coxson 2011), determines the duration of hydration periods (e.g. Gauslaa \& Solhaug 1998). Furthermore, species-specific internal factors influence lichen responses after hydration events (Jonsson et al. 2008). While several reviews pertaining to water relations 
in lichens have been published over the years (e.g. Blum 1973; Kappen 1973; Kershaw 1985; Green et al. 2011), an overview linking the various sources of hydration to lichen morphology, function and distribution is lacking. This study attempts to combine and compare spatial distribution of the three main water sources of rain, dew and humid air with water-related traits of epiphytic macrolichens in a conceptual and functional model that may be useful for future modelling of lichens in climate change scenarios.

\section{Main sources of hydration in lichens and their interaction with light}

In order to visualize hydration patterns, the three main atmospheric hydration sources for lichens, rain, water vapour condensation (dew) and humid air, are placed as corners in a triangle (Fig. 2). Each location inside the triangle represents a certain combination of hydration sources. Hydration sources are partly coupled: rain and dew necessarily imply high air humidity, but humid air can

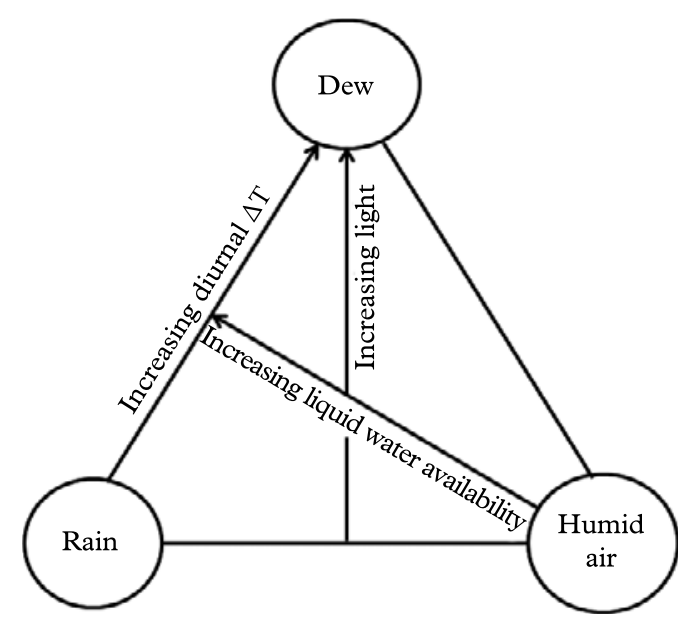

FIG. 2. Hydration source model for lichens, visualizing relationships between the three main sources of lichen hydration (rain, dew, humid air) and some important abiotic factors (temperature, light and liquid water availability). Each location inside the triangle represents a certain combination of hydration sources. $\triangle \mathrm{T}$ refers to the diurnal temperature amplitude. occur without the presence of liquid water. Liquid water can also come as fog/mist, but because fog provides droplets of water, fog is included under rain.

Light availability during hydration periods drives lichen photosynthesis and growth (Palmqvist 2000), although hydration during nights may also stimulate growth (Bidussi et al. 2013a). Even so, light availability (as shown in Fig. 2) is partly confounded with hydration sources (Stoutjesdijk \& Barkman 1987) because solar radiation is also a driver of surface temperatures and thus strongly influences water loss and air humidity. At physical scales relevant to lichen physiology, the air during daylight hours is often more humid in the shade of forests than in open, well-lit places, but this relationship becomes inverted at night when cooling is strongest outside a shielding canopy (Geiger 1950). This implies that dew is particularly frequent in forest gaps [open shade habitats sensu Stoutjesdijk (1974)] which receive much diffuse sky light but little direct sun. Indirect light stimulates lichen growth (Gauslaa et al. 2006, 2007). In marked contrast, direct exposure to sunlight causes rapid drying (Lange et al. 2004) and adversely impacts epiphytic lichen growth (Gauslaa \& Goward 2012; Bidussi et al. 2013b), although short-time sunflecks can have positive effects (Lakatos et al. 2006; Coxson \& Stevenson 2007a). Light experienced during prolonged dry periods causes much more damage than desiccation per se, and substantially retards photosynthetic activation during subsequent hydration (Lidén et al. 2010; Gauslaa et al. 2012), particularly in epiphytic cephalolichens and shade-adapted chlorolichens (Gauslaa \& Solhaug 1996; Jonsson Cabrajic et al. 2010).

\section{Spatial variation in hydration sources}

\section{Regional scales}

At regional scales (Fig. 3A), vegetation generally becomes more open and/or well spaced with increasing aridity (e.g. Walter \& Breckle 1984). Under otherwise similar conditions, nocturnal cooling is much stronger 
Spatial scales:

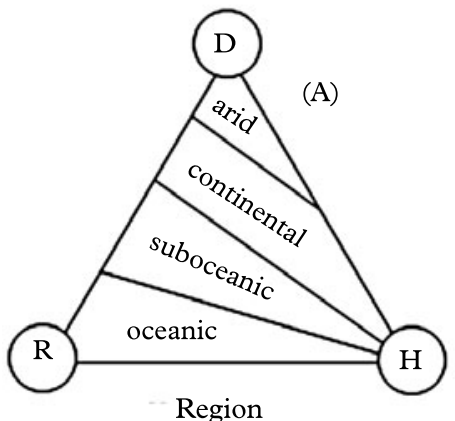

Region

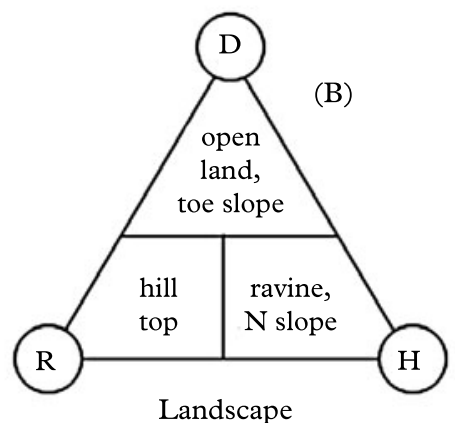

Landscape

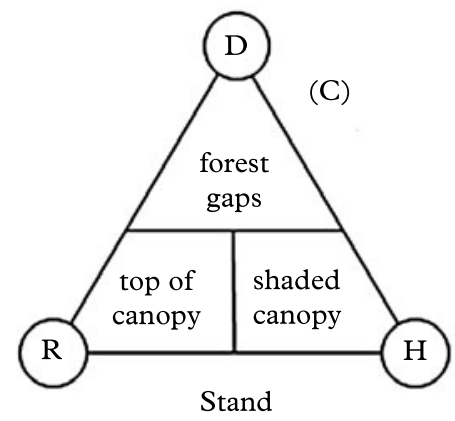

Stand

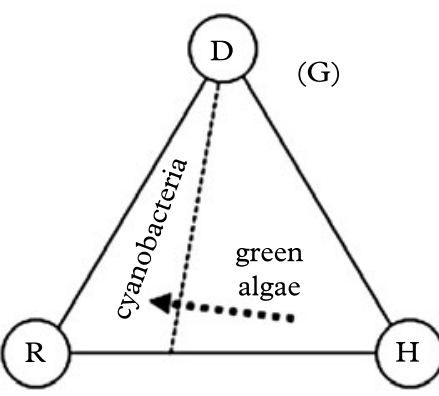

Photobiont type

H)

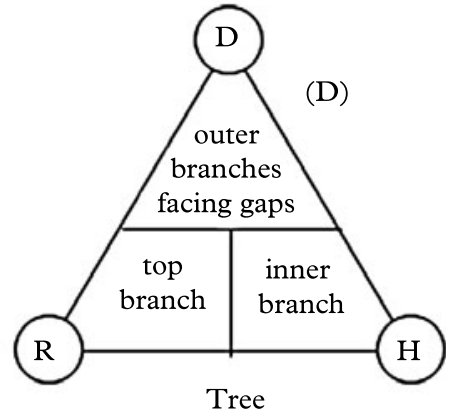

焉
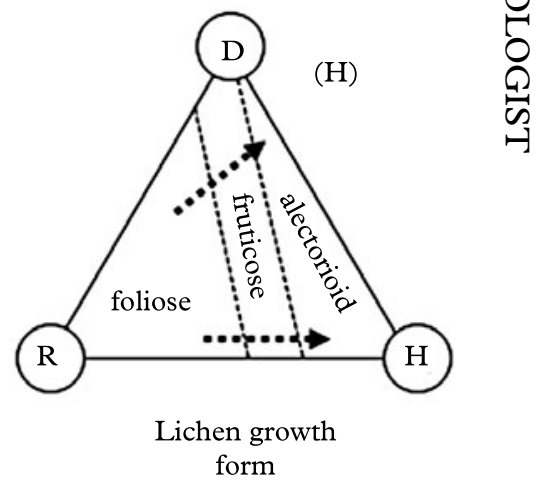

Thallus thickness, water holding capacity

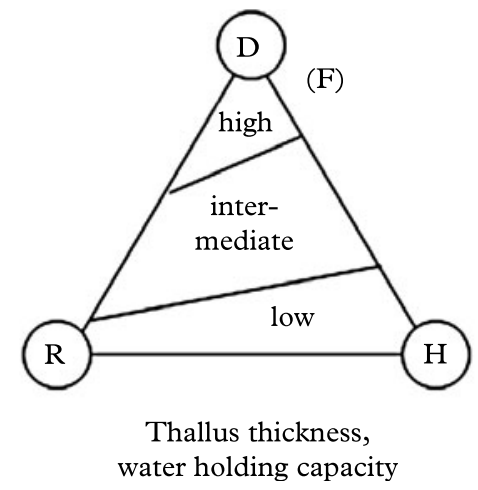

Suprasaturation
depression frequency

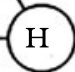

Fig. 3. Basic ideas and hypo

forest lichens to hydration sources. 
in open spaces than inside forests (Stoutjesdijk \& Barkman 1987). Pre-dawn dewfall in open habitats (Fig. 3B-D) increases with decreasing cloud cover (Xiao et al. 2013), increasing nocturnal cooling and thus increasing air humidity (e.g. Geiger 1950). A critical wind speed is needed to maximize dewfall rates; if wind is faster, which is often the case in coastal sites, condensation is offset by turbulent warming; if too slow, water for condensation cannot be replenished from humid air above (Oke 1987; Xiao et al. 2013). Strong dew formation is thus more common in inland climates (Fig. 3A). Dew and humid air in particular, are inaccessible to most vascular plants, but useful to lichens. Dry valleys of south-eastern Norway, located in rain shadows behind snow-capped mountains, have merely $300 \mathrm{~mm}$ rainfall (Fig. 4) and are surrounded by fairly dry areas ( $<700 \mathrm{~mm}$ according to Moen 1999; see Fig. 4). Surprisingly, these low rainfall areas support some oceanic lichens (Tønsberg et al. 1996). One example is Menegazzia terebrata (Fig. 4), which mainly grows on tree trunks in rainforests receiving $\geq 2000 \mathrm{~mm}$ rain along the western coast (enclosed by the solid line in Fig. 4; Moen 1999). Because canopies reduce the nocturnal cooling required for reaching the dew point, oceanic epiphytes cannot grow on their normal substratum of bark in the dry inland. Yet, they thrive on boulders and rocks in open, lowrainfall inland valleys. Their location in valleys with cold-air ponding ensures some, but little, wind replenishing moisture at ground level and causes heavy nocturnal dewfall (Oke 1987). Lichens in places with frequent dew experience less nutrient loss to leaching than their counterparts in rainy climates. This may contribute to higher diversity and abundance of members of the generally nutrient-demanding taxonomic groups Physciaceae and Teloschistales in dry valleys, compared to leached coastal and montane rainforests where such species are strongly associated with eutrophic habitats.

Dewfall can also be frequent in some deserts, as for example the Negev Desert which receives dew on an average of 198 nights per year (Lange et al. 1970, 1990). In the Namib
Desert, dew alone resulted in photosynthetic activation providing $58-63 \%$ of total carbon gain in three epiphytic lichens (Lange et al. 2007). In the arid coastal parts of northern Chile, condensation is so strong that fog oases develop, associated with fairly hydrophytic lichen communities on spines of cacti (Lange \& Redon 1983; Redon \& Lange 1983). Dew events can be rare and/or seasonal in some arid habitats, but nocturnal cooling may still substantially raise the humidity and thus activate lichen photosynthesis (Lange et al. 1970).

Rain is most frequent on mountainous coasts along large oceans subjected to convective energy and moisture from the sea (Fig. 3A). Winds and cloud cover reduce nocturnal cooling. Hence there is often a trade-off between rainfall and dewfall. For example, the mean diurnal temperature amplitude increases from the rainy Pacific coastal forests of north-western North America to the inland rainforests further east (Table 1-1 in DellaSala et al. 2011b) with much less rain (Stevenson et al. 2011; 788$1240 \mathrm{~mm}$ per year). The occurrence of similar epiphytic vegetation in these two areas (Goward \& Spribille 2005; Radies et al. 2009; DellaSala et al. 2011a), supporting many liquid water-demanding cyanolichens (Goward \& Arsenault 2000), is probably caused by heavy dewfall compensating for less rain inland. In fact, cephalo- and cyanolichens became fully hydrated every morning by pre-dawn dew over two dry August weeks in the inland of British Columbia (Y. Gauslaa, pers. obs.). Because dew measured in $\mathrm{mm}$ of water is not enough to compensate for the large reduction in rainfall from the coast to the inland, the frequency of hydration rather than the total amount of rainfall matters for the rainforest lichen community.

\section{Landscape scales}

Stepping from regions down to a landscape scale, rainfall increases in intensity and frequency with altitude (orographic rain; e.g. Roe 2005) and thus causes longer periods of hydration on hill tops and rough terrain (Fig. 3B). Dewfall (Fig. 3B) is strong in lower 
Vol. 46

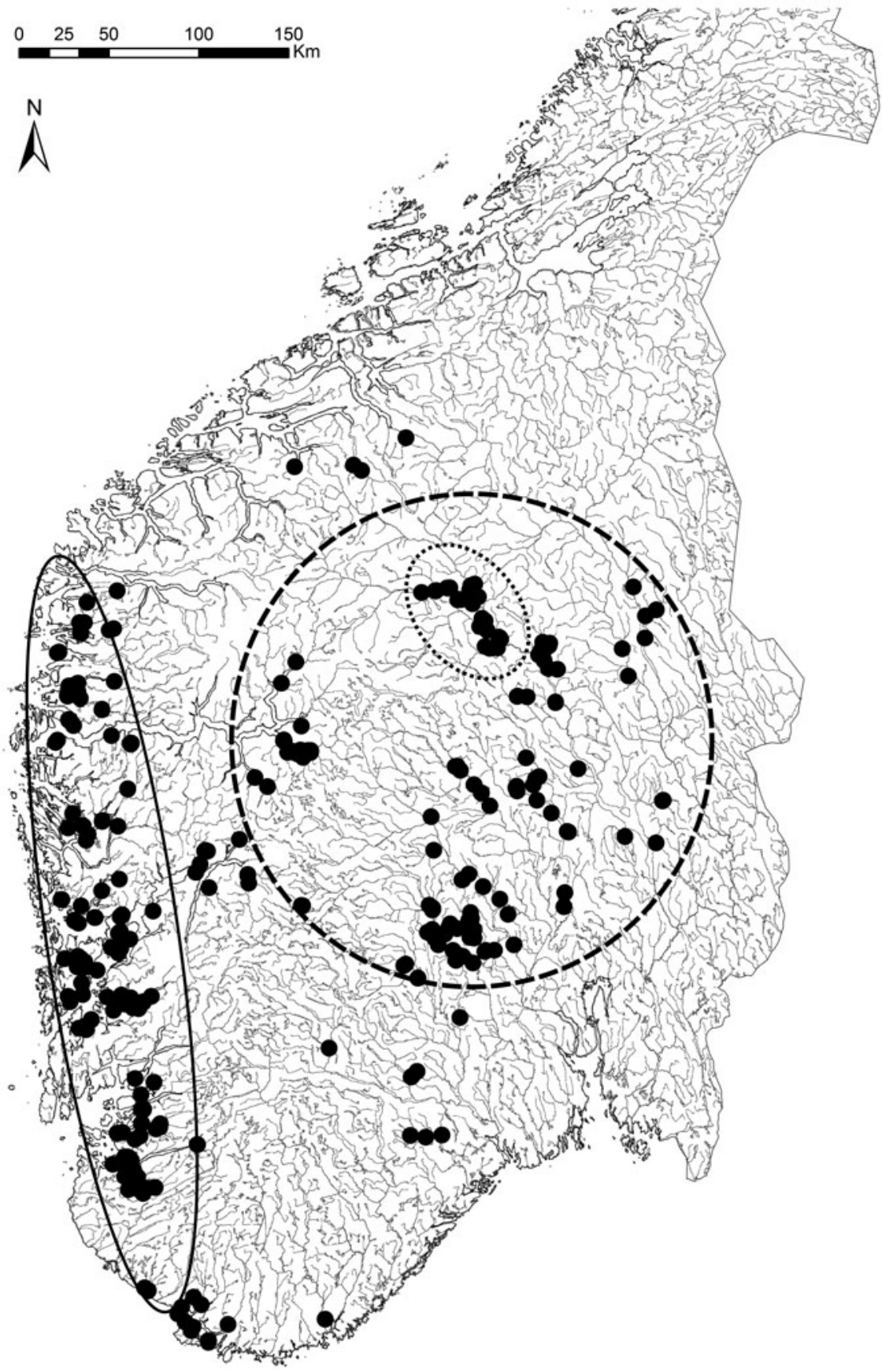

FIG. 4. Distribution map of Menegazzia terebrata in southern Norway, generated 24 October 2013 from the Norwegian Lichen Database (http://nhm2.uio.no/lav/web/index.html), The Lichen Herbarium, Natural History Museum, University of Oslo. Solid line oval: rainforest region $(\geq 2000 \mathrm{~mm}$ rain) of western Norway with mainly epiphytic occurrences. Dotted line oval: rain shadow sites in dry inner valleys (300 $\mathrm{mm}$ rain). Short dashed circle: relatively dry areas ( $\leq 700 \mathrm{~mm}$ rainfall). In the dry areas the species grows on rocks and boulders in open landscapes. 
parts of U-shaped valleys influenced by coldair ponding (Oke 1987). Thereby a trade-off between increasing orographic rain and decreasing pre-dawn dew may occur with altitude above the valley bottom. As orographic rain is common during daytime, whereas pre-dawn dew consistently occurs at the diurnal minimum temperature, the growth rates of lichens in U-shaped valleys are not necessarily affected by elevation (Bidussi et al. 2013b). Dew is also frequent on northern slopes in the Northern Hemisphere (Kappen et al. 1980), where photosynthetic periods for lichens are substantially prolonged compared to eastern slopes (Lange et al. 1970).

Humid air habitats are forested ravines, shaded mountainsides and the surroundings of water bodies and mire complexes.

\section{Stand scales}

At a stand level (Fig. 3C), clear-cuts and forest gaps of certain sizes (Geiger 1950) are associated with frequent dew, particularly at northern exposures. Dew is probably an important reason why transplanted old forest lichens sometimes grow better in sheltered clear-cuts than inside intact old forests (Gauslaa et al. 2006; Larsson et al. 2012). Epiphytic lichens are not necessarily absent in clear-cuts just because of low water availability, but because stable substrata are scarce or absent. However, intact forests retain humidity after, for example, rain for longer periods than open sites during daylight, allowing accumulation of high lichen biomass (Esseen et al. 1996; see also Fig. 1 showing high biomass loadings).

\section{Tree scales}

Moving to the spatial scale of a tree (Fig. 3D), rain drains away from the stem and from the inner parts of the canopy (Beier et al. 1993), especially in the centrifugal type of crowns with hanging branches like most conifers (as reviewed by Barkman 1958). Rainfall is thus heaviest in the upper crown and in outer portions of branches. At the same time, dewfall is heaviest in the outer portions of branches at the north-facing edges of large gaps (Stoutjesdijk 1974; Stoutjesdijk \& Barkman 1987), where light is optimal for lichen growth. Dew can also be substantial in the upper, exposed canopy (Lüdi \& Zoller 1953). Generally speaking, the lower forest canopy tends to be humid during the day (Geiger 1950), but lower canopy lichens often experience insufficient light for rapid growth. Slower drying inside shaded canopies compared to more lightexposed sites may partly compensate for the low photosynthetic rates associated with shade, although sunflecks have been shown to be important for the diurnal C-gain (Lakatos et al. 2006). Tree trunks and other habitats shielded from rain and run-off water may support ombrophobous lichen communities (see Barkman 1958), in which humidity is the only or main source of hydration. Recently, midday dew was found to be a significant source of humidity for crustose lichens on trunks in tropical rainforests (Lakatos et al. 2012) because of strongly delayed diurnal temperature minima in trunks acting as a heat reservoir. In principle, this should imply that the larger the trunk, the more delayed the dew event will be, leading to substantial benefits for tightly attached lichens because dew will then form during the daylight period. The highly interesting study of Lakatos et al. (2012) may explain why the lower portions of large trunks also in boreal and temperate environments often host rare lichens, and why ombrophobous lichen communities in old forests can host a high lichen diversity (Holien 1996). Such a mechanism depends on close thermal contact with the trunk. It thus works mainly for crustose lichens.

\section{Links between lichen functioning and water-holding capacity}

Water-holding capacity, WHC $=$ [saturated wet mass (WM) - dry mass (DM)] / thallus area (A), gives the amount of water at saturation. This parameter is based on the thallus area that takes up and transpires water, harvests light and fixes carbon. From an ecological perspective, WHC (Fig. 5A) is thus a more functional measure than percent water 


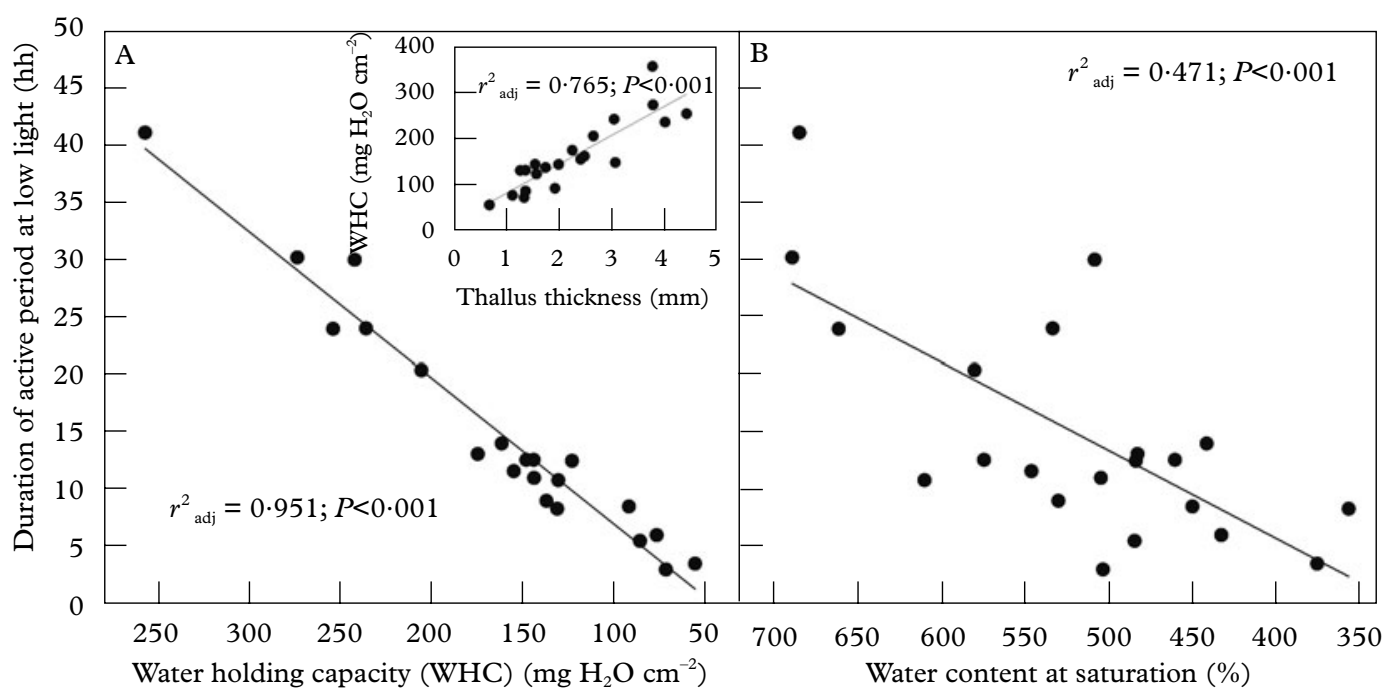

FIG. 5. The relationship between the duration of active metabolism in the cyanolichen Degelia plumbea at low light and A, the water-holding capacity (WHC) at saturation after shaking and B, the percent water content at the same conditions. The insert shows the relationship between WHC and the total thickness of the thalli studied with a size range of $1 \cdot 1-36 \cdot 4 \mathrm{~cm}^{2}$. The data are from Gauslaa \& Solhaug (1998); A is redrawn from this paper; B and the insert are unpublished plots from the same data set.

at saturation (Fig. 5B), which is equivalent to the parameter $\mathrm{WHC}_{\mathrm{DM}}=(\mathrm{WM}-\mathrm{DM}) /$ $\mathrm{DM}$. $\mathrm{WHC}_{\mathrm{DM}}$ is commonly used in fields such as soil science, but is less useful in lichen ecology. However, WHC as used in this paper $\left(=\mathrm{WHC}_{\mathrm{A}}\right)$ directly translates to rain or dewfall $\left(10 \mathrm{mg} \mathrm{H}_{2} \mathrm{O} \mathrm{cm} \mathrm{cm}^{-2}\right.$ equates to $0.1 \mathrm{~mm}$ dew or rain), and determines the duration of the physiologically active period across species and/or specimens subsequent to a hydration event (Fig. 5A).

Both WHC and percentage of water at saturation normally refer to water content after the fully hydrated thallus has been shaken or blotted with the proviso that water content is: 1) substantially higher after shaking than after blotting, and 2) higher when measured in the field than in the laboratory (i.e. owing to the presence of external water droplets; Lange et al. 1993a). WHC blotting mainly represents the internal WHC of a lichen thallus, whereas $\mathrm{WHC}_{\text {shaking }}-\mathrm{WHC}_{\text {blotting }}$ refers to external surface water removed by blotting (Green et al. 1985). Apparently, common rates of dewfall (Xiao et al. 2013) are often just enough to fill the $\mathrm{WHC}_{\text {blotting }}$ of an aver- age chlorolichen (Gauslaa \& Coxson 2011). The average $\mathrm{WHC}_{\text {blotting }}$ across lichens studied is $20 \mathrm{mg} \mathrm{H}_{2} \mathrm{O} \mathrm{cm}^{-2}$ (Gauslaa \& Coxson 2011) and can fully utilize an average good dewfall of $0.2 \mathrm{~mm}$ (Jacobs et al. 2002, 2006; Richards 2002; Hao et al. 2012; Xiao et al. 2013). Such a link suggests that many lichens have evolved to function optimally with dew rather than rain. This hypothesis is consistent with the findings of Lange (Lange 2003) showing the importance of days with dew, but no rain, for the annual lichen carbon gain. By contrast, $\mathrm{WHC}_{\text {shaking }}$ can mainly be filled with rain, as maximal dewfall rates seem to be just 0.04 $\mathrm{mm} \mathrm{h}^{-1}$ (Xiao et al. 2013). Thus both these WHC measures are ecologically relevant. Measurement of $\mathrm{WHC}_{\text {blotting }}$ is simpler to reproduce and compare, evidenced by the substantially lower standard errors (Table 1). For the lichens studied (Table 1), the average $\mathrm{WHC}_{\text {shaking }} / \mathrm{WHC}_{\text {blotting }}$ ratio was $1.4-$ $2 \cdot 1$. Therefore blotting removes substantial amounts of water. There is a need for

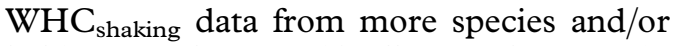
habitats. Unless specifically stated, WHC in this paper refers to $\mathrm{WHC}_{\text {blotting }}$. 
TABLE 1. Comparison of water-holding capacity (mean \pm standard error; in $m g \mathrm{H}_{2} \mathrm{O} \mathrm{cm}^{-2}$ ) after shaking (WHC shaking) and after blotting ( $W H C_{\text {blotting }}$ ) in four lichen species.

\begin{tabular}{llrrrr}
\hline Species & Photobiont & $n$ & WHC $_{\text {blotting }}$ & WHC $_{\text {shaking }}$ & sh/bl ratio \\
\hline Xanthoria aureola* $^{*}$ & Chloro & 15 & $40 \cdot 5 \pm 1 \cdot 6$ & $91 \cdot 2 \pm 8 \cdot 5$ & $2 \cdot 3$ \\
Hypogymnia occidentalis $^{\dagger}$ & Chloro & 200 & $19 \cdot 1 \pm 0 \cdot 4$ & $39 \cdot 7 \pm 0 \cdot 7$ & $2 \cdot 1$ \\
Lobaria pulmonaria $^{\dagger}$ & Cephalo & 200 & $12 \cdot 4 \pm 0 \cdot 1$ & $17 \cdot 1 \pm 0 \cdot 2$ & $1 \cdot 4$ \\
Pseudocyphellaria dissimilis $^{*}$ & Cyano & 3 & $13 \cdot 3 \pm 1 \cdot 9$ & $25 \cdot 7 \pm 4 \cdot 1$ & $1 \cdot 9$ \\
\hline
\end{tabular}

* Gauslaa \& Ustvedt (2003); ${ }^{\dagger}$ Gauslaa \& Goward (2012) $\mathrm{WHC}_{\text {shaking }}$ unpublished data; ${ }^{\star}$ Computed from data in Green et al. (1985).

Gauslaa \& Coxson (2011) showed that specific thallus mass, $S T M=D M / A$, is the important driver for WHC in foliose lichens (Fig. 3F). STM is the inverse equivalent of the frequently used parameter specific leaf area $(\mathrm{SLA}=\mathrm{A} / \mathrm{DM})$ in plant sciences (e.g. Poorter \& Remkes 1990), intimately connected to the resource use economy of plants (Reich et al. 1998; Wright et al. 2004). This parameter was emphasized by Kershaw (1985) as an important lichen parameter for water loss and water uptake. STM is a rough measure of thallus thickness, and is higher in sun-adapted than in shade-adapted thalli. With increasing solar radiation exposure in nature from shaded forests to open sea cliffs, STM in studied chlorolichens increased from c. 7 (shade-adapted Platismatia glauca) to $70 \mathrm{mg} \mathrm{DM} \mathrm{cm}{ }^{-2}$ (Anaptychia runcinata thalli from open seashore), with a concurring increase in WHC from 7 to $70 \mathrm{mg} \mathrm{H}_{2} \mathrm{O} \mathrm{cm} \mathrm{cm}^{-2}$ (Gauslaa \& Coxson 2011). The 1:1 relationship found between WHC and STM in many foliose chlorolichens (Gauslaa \& Coxson 2011) was also shown to hold fairly well for fruticose epiphytic chlorolichens in an oceanic oak forest in south-western Norway (Fig. 6; original data). Also for fruticose lichens, intraand interspecific differences in WHC occur (Fig. 6). The strong 1:1 WHC-STM relationship for chlorolichens implies that WHC $\approx$ STM. Because lichen wet mass at saturation per thallus area (WM) $=\mathrm{STM}+\mathrm{WHC}$, a rough estimate of WHC in a chlorolichen approximates WM/2. The 1:1 WHC-STM relationship in Fig. 6 shows that enhanced internal water storage requires additional investment in carbon per thallus area, which in turn may imply a change in the balance between water use efficiency versus light use efficiency. The contrasts in thallus thickness between species suggest that STM is at least partly genetically determined.

The intraspecific variation in STM and WHC for the fruticose lichens (see Fig. 6) is mainly an effect of thallus size (data not shown). A range of sizes from small to large was measured for all species, and STM and WHC positively correlated with size. Also, for foliose canopy lichens WHC strongly increases with thallus size, from tiny juveniles to old reproducing stages (Merinero et al. 2014). As common intensities of dew and low rainfall match the WHC of specific size classes of lichens, the local hydration regime probably influences the maximal size of a lichen species in a given habitat.

Acclimation of STM has been noted after lichens were transplanted to new environments (e.g. Gauslaa et al. 2006, 2009). From a seasonal perspective, STM significantly increases when the lichen is exposed to high light and dry conditions, and again decreases during long darker and wetter periods (Larsson et al. 2012). Intraspecific STM responses triggered by increasing evaporative demands have also been noted in natural populations (Snelgar \& Green 1981; Gauslaa \& Coxson 2011; Merinero et al. 2014). To generalize, changes in STM effectively improve the storage of water in sites and during times when hydration is suboptimal. Prolonged exposure to full hydration has a stronger positive impact on thallus area growth than on biomass gain (Bidussi et al. 2013a), presumably because prolonged high turgor pressure stimulates fungal expansion, as discussed by Larsson et al. (2012) and Bidussi 


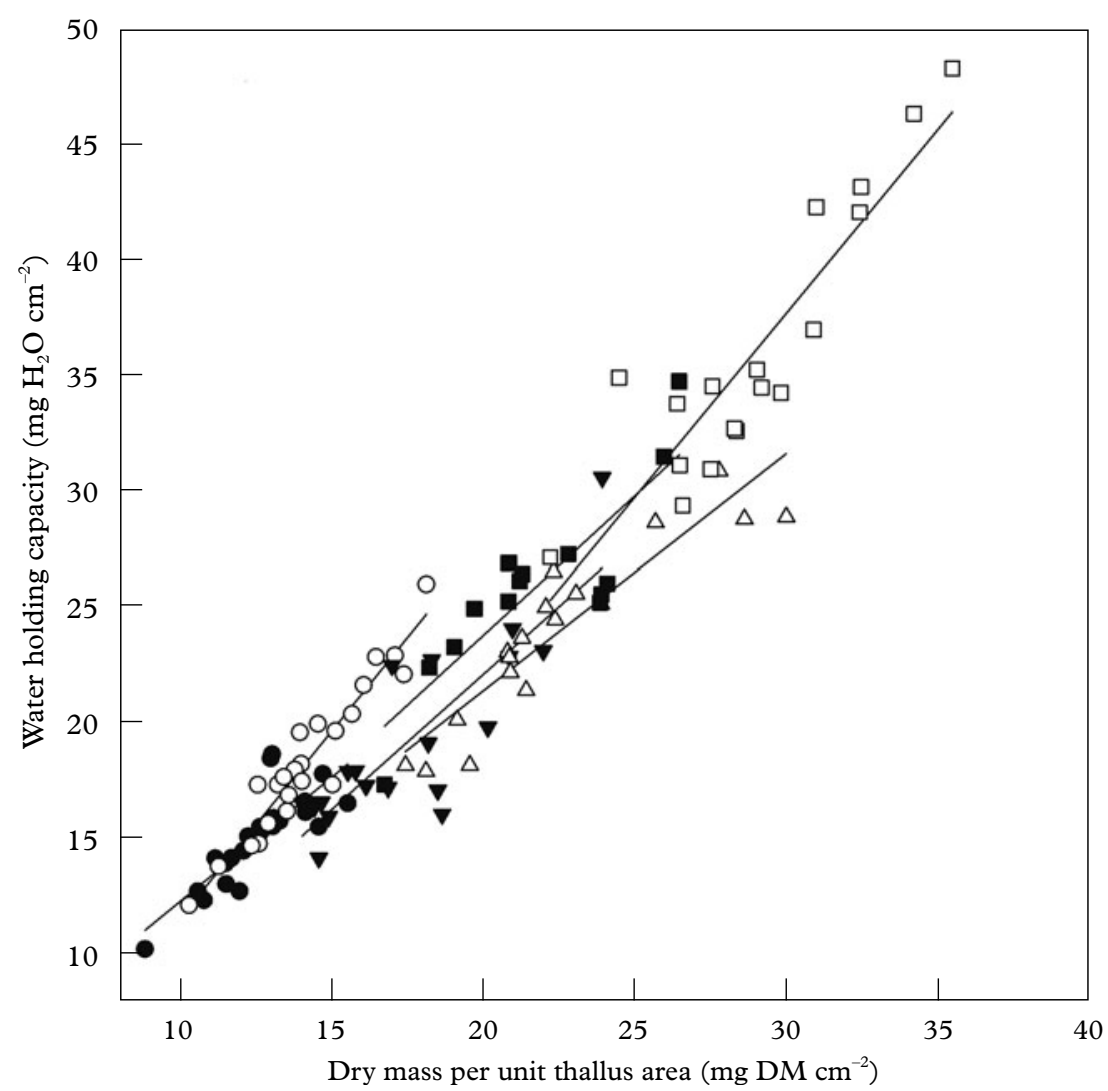

FIG. 6. Specific thallus mass ( $\mathrm{mg}$ dry matter $\mathrm{cm}^{-2}$ ) and water-holding capacity $\left(\mathrm{mg} \mathrm{H}_{2} \mathrm{O} \mathrm{cm}^{-2}\right)$ in fully hydrated thalli after removing surface water by blotting. All fruticose epiphytic lichen species found in an Atlantic oak forest in Spindanger, Farsund, south-western Norway were included. $\bullet$, Evernia prunastri; $\bigcirc$, Pseudevernia furfuracea, $\mathbf{\nabla}$, Ramalina farinacea; $\triangle$, Usnea cornuta; $\mathbf{\square}$, Usnea subfloridana; $\square$, Sphaerophorus globosus; species specific regression lines are shown. Thallus area in E. prunastri, P. furfuracea, $R$. farinacea and S. globosus was measured with a LI3100 Licor Area Meter (Lincoln, Nebraska, USA); areas in the two Usnea spp. were computed by imaging tools (ImageJ $1.46 \mathrm{f}$ version). In all species, a range of thallus sizes as measured (original data)

et al. (2013a). Such responses probably tune the WHC to seasonal and spatial evaporative demands.

\section{Lichen responses to hydration sources}

Many green algal lichens (chloro- and cephalolichens) can initiate photosynthetic activity in the absence of liquid moisture, although activation in humid air often occurs at slow rates (Jonsson Cabrajic et al. 2010). The relative humidity needs to exceed $75-80 \%$, corresponding to a water potential $\approx-38$
MPa (Nash III et al. 1990) or lower (Green et al. 2011). Therefore, the term 'humid air' in Fig. 2 (right corner) refers to humidity levels above $\approx 80 \%$. Cyanolichens by contrast require liquid water as rain or dew to initiate normal photosynthesis (Lange et al. 1986, 1988, 1989, 1993b); their photosynthetic water compensation point is much higher than in chlorolichens, as reviewed by Green et al. (2011). Accordingly, cyanolichens are restricted to the left portion of the triangle, indicating a requirement for dew and rain (see e.g. Marini et al. 2011), whereas chloro- and cephalolichens utilize all 
available hydration sources and are hence, as a group, more widespread (Fig. 3G). The fact, however, that cyanolichens often have substantially higher WHC than chloro- and cephalolichens (Gauslaa \& Coxson 2011), may partly compensate for their more stringent hydration requirements for photosynthetic activation. At the same time, the cyanolichen Lobaria scrobiculata requires $2 \cdot 5$ times greater hydration for activation than the cephalolichen L. pulmonaria (MacKenzie \& Campbell 2001), which complicates the story and emphasizes the need for further studies on lichen water use efficiency, as proposed by Máguas et al. (1997).

The bottom panel of triangles (Fig. 3E$\mathrm{H})$ summarizes various lichen responses to hydration. Excess hydration by liquid water often suppresses lichen photosynthesis, a phenomenon referred to as suprasaturation depression (Lange \& Matthes 1981; Lange et al. 1993a, 2001). Suprasaturation depression does not occur during water uptake in humid air, but can instantaneously take place after additional spraying with water (Lange \& Kilian 1985), unless the lichen surface is water-repellent (Lakatos et al. 2006; Hauck et al. 2008; Pardow et al. 2010). In a continuous year-long gas exchange measurement of the chlorolichen Lecanora muralis in an open habitat in Germany, 74 days of heavy rain resulted in only $2.4 \%$ of the annual carbon gain, whereas 105 days with dew accounted for $40 \%$ (Lange 2003). Depression of lichen photosynthesis by excess water is thus common in rainy events, rare with dew, and absent in humid air (Fig. 3E). As bryophytes in general are much better than lichens in handling excess water (Green et al. 2011), there is a higher bryophyte/lichen biomass ratio in rainy regions where bryophytes rather than lichens tend to dominate tree canopies.

Finely dissected and/or thin lichens (Fig. 1A) take up humidity rapidly, whereas thick and/or compact growth forms need a long time to become hydrated in humid air (Larson \& Kershaw 1976; Larson 1981; Lange \& Kilian 1985; Lange et al. 1986). Chlorolichens across studied macrolichen growth forms and taxonomic groups follow the 1:1 line in WHC-STM plots, equivalent to $\approx 100 \%$ water at saturation [Fig. 5 shows this for fruticose lichens; Gauslaa \& Coxson (2011) shows foliose lichens]. Epiphytic cyanolichens tend to follow the 2:1 line equivalent to $\approx 200 \%$ water (Gauslaa \& Coxson 2011). Such relationships suggest that chlorolichens have an opportunistic water economy, as the lower mass per thallus area allows more rapid use of humidity from the air. Cyanolichens have a more conservative water economy. They need higher water content in order to maximize the duration of hydration to compensate for the rarer hydration events by liquid water.

Alectorioid lichens (Figs $1 \mathrm{~A} \& 3 \mathrm{H}$ ) are among the lichens with the largest surface area to biomass ratio. Among the alectorioid lichens, Bryoria species and Ramalina thrausta are the thinnest. As chlorolichens, they rapidly activate photosynthesis in equilibrium with high ambient air humidity (Lange et al. 1986). Bryoria biomass is much higher in inland regions with less rain than in coastal forests subjected to heavy rain (as shown for Scandinavia by Ahlner 1948; Bruteig 1993). Furthermore, excess rain or melting water from snow has been shown to damage Bryoria in western North America (Goward 1998), as well as being associated with temporary Bryoria dieback in Norwegian spruce canopies during unusually wet autumns (Y. Gauslaa, pers. obs.). Similar die-off events have been observed in foliose chlorolichens during an exceptional wet late autumn when no damage occurred in cephalo- and cyanolichens (Gauslaa 2002). The alectorioid genus Usnea is more flexible with respect to water sources than Bryoria, Alectoria and Ramalina thrausta. The genus as such has a highly variable morphology and anatomy (Motyka 1947), and occurs in well-lit portions of rainforests in most regions of the world (Halonen et al. 1998; Kantvilas \& Jarman 1999; Antoine \& McCune 2004), as well as in drier forests with abundant Bryoria biomass. Usnea is often represented with more species in the more oceanic areas than in dry areas (Bjerke et al. 2006), and growth rates in species such as Usnea longissima increase with increasing rainfall (Gauslaa et al. 2007). The Usnea species 
shown in Fig. 6 have fairly high WHC, but they came from a coastal site where rain and wind are frequent and dew rarely appears, and where no specimens of Bryoria occurred. In contrast to other alectorioid lichens (Alectoria, Bryoria, Ramalina thrausta), thick coastal Usnea species may depend on rain and may thus have optimized their water storage.

Individual lichen species may occupy narrow or wide species-specific areas within the triangle in Fig. 2. To give a few examples, the delicate, pendulous, capillary branches of Ramalina thrausta are apparently optimized for rapid, highly efficient activation in humid air, an inference supported by this species' remarkable ability to inhabit sites partially sheltered from rain and dew. By contrast, the foliose genera Sticta and Pseudocyphellaria, including cephalo- as well as cyanolichen members, inhabit rainy climates (Green \& Lange 1991). Apparently, the presence of cyphellae and pseudocyphellae in Sticta and Pseudocyphellaria, respectively, permits $\mathrm{CO}_{2}$ exchange through the lower cortex which allows more of the remaining thallus to store water without too severe suprasaturation depression (Green et al. 1981, 1985). Suprasaturation depression under rainforest conditions was less, or even absent, in Sticta at $500 \%$ water content having cyphellae than in Lobaria in which these structures are lacking (Lange et al. 2004). Another rain-dependent species is the cyanolichen Degelia plumbea, with such a high WHC (Gauslaa \& Solhaug 1998) that it can never be fully activated by dew alone.

\section{Conclusion}

Various groups and species of epiphytic lichens have specialized morphology, anatomy and symbiotic relationships in order to function optimally under specific hydration regimes. In this respect, growth forms and photobiont type are important lichen traits. There is a need to quantify STM and WHC in more lichen species and growth forms. So far, WHC data are lacking for the many green-algal pendulous and fruticose lichens, as well as for cyanobacterial gel lichens. Another promising investigation would be to study the links between STM and activation time of photosynthetic acitivity in chloroand cephalolichens in humid air. Such data are needed to establish quantitative links between availability of hydration sources and lichen traits in the model (Fig. 3E-H). Specifying the sources of hydration and including internal lichen variables such as water-holding capacity will probably improve modelling local and global future scenarios on lichen distribution and biomass production.

This study was supported by Formas, Sweden, through a grant (230-2011-1559) to Per-Anders Esseen. Thanks go to him for useful discussions. Thanks also to Trevor Goward for comments, discussions and field visits from the start to the end of this work, and to Michael Lakatos and Kristin Palmqvist for their constructive referee comments.

\section{REFERENCES}

Ahlner, S. (1948) Utbredningstyper bland Nordiska barrträdslavar. Acta Phytogeographica Suecica 22: 1257.

Antoine, M. E. \& McCune, B. (2004) Contrasting fundamental and realized ecological niches with epiphytic lichen transplants in an old-growth Pseudotsuga forest. Bryologist 107: 163-172.

Barkman, J. J. (1958) Phytosociology and Ecology of Cryptogamic Epiphytes. Assen: van Gorcum.

Beier, C., Hansen, K. \& Gundersen, P. (1993) Spatial variability of throughfall fluxes in a spruce forest. Environmental Pollution 81: 257-267.

Bidussi, M., Gauslaa, Y. \& Solhaug, K. A. (2013a) Prolonging the hydration and active metabolism from light periods into nights substantially enhances lichen growth. Planta 237: 1359-1366.

Bidussi, M., Goward, T. \& Gauslaa, Y. (2013b) Growth and secondary compound investments in the epiphytic lichens Lobaria pulmonaria and Hypogymnia occidentalis transplanted along an altitudinal gradient in British Columbia. Botany 91: 621-630.

Bjerke, J. W., Elvebakk, A. \& Elverland, E. (2006) The lichen genus Usnea in Norway north of the Arctic Circle: biogeography and ecology. Nova Hedwigia 83: 293-309.

Blum, O. B. (1973) Water relations. In The Lichens (V. Ahmadjian \& M. E. Hale, eds): 381-400. New York: Academic Press.

Bolliger, J., Bergamini, A., Stofer, S., Kienast, F. \& Scheidegger, C. (2007) Predicting the potential spatial distributions of epiphytic lichen species at the landscape scale. Lichenologist 39: 279-291.

Braidwood, D. \& Ellis, C. J. (2012) Bioclimatic equilibrium for lichen distributions on disjunct continental landmasses. Botany 90: 1316-1325.

Brunialti, G. \& Frati, L. (2007) Biomonitoring of nine elements by the lichen Xanthoria parietina in Adriatic Italy: a retrospective study over a 7 -year time span. Science of the Total Environment 387: 289-300. 
Bruteig, I. E. (1993) Large-scale survey of the distribution and ecology of common epiphytic lichens on Pinus sylvestris in Norway. Annales Botanici Fennici 30: $161-179$.

Cislaghi, C. \& Nimis, P. L. (1997) Lichens, air pollution and lung cancer. Nature 387: 463-464.

Cornelissen, J. H. C., Callaghan, T. V., Alatalo, J. M., Michelsen, A., Graglia, E., Hartley, A. E., Hik, D. S., Hobbie, S. E., Press, M. C., Robinson, C. H., et al. (2001) Global change and arctic ecosystems: is lichen decline a function of increases in vascular plant biomass? Fournal of Ecology 89: 984-994.

Coxson, D. S. \& Stevenson, S. K. (2007a) Growth rate responses of Lobaria pulmonaria to canopy structure in even-aged and old-growth cedar-hemlock forests of central-interior British Columbia, Canada. Forest Ecology and Management 242: 5-16.

Coxson, D. S. \& Stevenson, S. K. (2007b) Influence of high-contrast and low-contrast forest edges on growth rates of Lobaria pulmonaria in the inland rainforest, British Columbia. Forest Ecology and Management 253: 103-111.

DellaSala, D. A., Alaback, P., Craighead, L., Goward, T., Paquet, P. \& Spribille, T. (2011a) Temperate and boreal rainforests of inland northwesten North America. In Temperate and Boreal Rainforests of the World (D. A. DellaSala, ed.): 82-110. Washington: Island Press.

DellaSala, D. A., Alaback, P., Spribille, T., von Wehrden, H. \& Nauman, R. S. (2011b) Just what are temperate and boreal rainforests? In Temperate and Boreal Rainforests of the World (D. A. DellaSala, ed.): 1-41. Washington: Island Press.

Eaton, S. \& Ellis, C. J. (2012) Local experimental growth rates respond to macroclimate for the lichen epiphyte Lobaria pulmonaria. Plant Ecology and Diversity 5: 365-372.

Ellis, C. J., Coppins, B. J. \& Dawson, T. P. (2007a) Predicted response of the lichen epiphyte Lecanora populicola to climate change scenarios in a clean-air region of Northern Britain. Biological Conservation 135: 396-404.

Ellis, C. J., Coppins, B. J., Dawson, T. P. \& Seaward, M. R. D. (2007b) Response of British lichens to climate change scenarios: trends and uncertainties in the projected impact for contrasting biogeographic groups. Biological Conservation 140: 217-235.

Esseen, P. A. \& Renhorn, K. E. (1998) Edge effects on an epiphytic lichen in fragmented forests. Conservation Biology 12: 1307-1317.

Esseen, P. A., Renhorn, K. E. \& Pettersson, R. B. (1996) Epiphytic lichen biomass in managed and old-growth boreal forests: effect of branch quality. Ecological Applications 6: 228-238.

Frati, L., Brunialti, G. \& Loppi, S. (2008) Effects of reduced nitrogen compounds on epiphytic lichen communities in Mediterranean Italy. Science of the Total Environment 407: 630-637.

Fritz, Ö., Gustafsson, L. \& Larsson, K. (2008) Does forest continuity matter in conservation? A study of epiphytic lichens and bryophytes in beech forests of southern Sweden. Biological Conservation 141: 655668 .
Galun, M. (1963) Autecological and synecological observations on lichens of the Negev, Israel. Israel fournal of Botany 12: 179-187.

Gauslaa, Y. (1995) The Lobarion, an epiphytic community of ancient forests, threatened by acid rain. Lichenologist 27: 59-76.

Gauslaa, Y. (2002) Die back of epiphytic lichens in SE Norway - can it be caused by high rainfall in late autumn? Graphis Scripta 13: 33-35.

Gauslaa, Y. \& Coxson, D. (2011) Interspecific and intraspecific variations in water storage in epiphytic old forest foliose lichens. Botany 89: 787-798.

Gauslaa, Y. \& Goward, T. (2012) Relative growth rates of two epiphytic lichens, Lobaria pulmonaria and Hypogymnia occidentalis, transplanted within and outside of Populus dripzones. Botany 90: 954-965.

Gauslaa, Y. \& Solhaug, K. A. (1996) Differences in the susceptibility to light stress between epiphytic lichens of ancient and young boreal forest stands. Functional Ecology 10: 344-354.

Gauslaa, Y. \& Solhaug, K. A. (1998) The significance of thallus size for the water economy of the cyanobacterial old forest lichen Degelia plumbea. Oecologia 116: $76-84$.

Gauslaa, Y. \& Ustvedt, E. M. (2003) Is parietin a UV-B or a blue-light screening pigment in the lichen Xanthoria parietina? Photochemical and Photobiological Sciences 2: 424-432.

Gauslaa, Y., Lie, M., Solhaug, K. A. \& Ohlson, M. (2006) Growth and ecophysiological acclimation of the foliose lichen Lobaria pulmonaria in forests with contrasting light climates. Oecologia 147: 406-416.

Gauslaa, Y., Palmqvist, K., Solhaug, K. A., Holien, H., Hilmo, O., Nybakken, L., Myhre, L. C. \& Ohlson, M. (2007) Growth of epiphytic old forest lichens across climatic and successional gradients. Canadian fournal of Forest Research 37: 1832-1845.

Gauslaa, Y., Palmqvist, K., Solhaug, K. A., Hilmo, O., Holien, H., Nybakken, L. \& Ohlson, M. (2009) Size-dependent growth in two old-growth associated macrolichens species. New Phytologist 181: 683-692.

Gauslaa, Y., Coxson, D. S. \& Solhaug, K. A. (2012) The paradox of higher light tolerance during desiccation in rare old forest cyanolichens than in more widespread co-occurring chloro- and cephalolichens. New Phytologist 195: 812-822.

Geiger, R. (1950) The Climate Near the Ground. Cambridge: Harvard University Press.

Goward, T. (1998) Observations on the ecology of the lichen genus Bryoria in high elevation conifer forests. Canadian Field-Naturalist 112: 496-501.

Goward, T. \& Arsenault, A. (2000) Cyanolichens and conifers: implications for global conservation. Forest Snow and Landscape Research 75: 303-318.

Goward, T. \& Spribille, T. (2005) Lichenological evidence for the recognition of inland rain forests in western North America. Fournal of Biogeography 32: 1209-1219.

Green, T. G. A. \& Lange, O. L. (1991) Ecophysiological adaptations of the lichen genera Pseudocyphellaria and Sticta to south temperate rainforests. Lichenologist 23: 267-282. 
Green, T. G. A., Snelgar, W. P. \& Brown, D. H. (1981) Carbon dioxide exchange in lichens - carbon dioxide exchange through the cyphellate lower cortex of Sticta latifrons Rich. New Phytologist 88: 421-426.

Green, T. G. A., Snelgar, W. P. \& Wilkins, A. L. (1985) Photosynthesis, water relations and thallus structure of Stictaceae lichens. In Lichen Physiology and Cell Biology (D. H. Brown, ed.): 57-75. New York: Plenum Press.

Green, T. G. A., Sancho, L. G. \& Pintado, A. (2011) Ecophysiology of desiccation/ rehydration cycles in mosses and lichens. Ecological Studies 215: 89-120.

Halonen, P., Clerc, P., Goward, T., Brodo, I. M. \& Wulff, K. (1998) Synopsis of the genus Usnea (lichenized Ascomycotina) in British Columbia, Canada. Bryologist 101: 36-60.

Hao, X. M., Li, C., Guo, B., Ma, J. X., Ayup, M. \& Chen, Z. S. (2012) Dew formation and its longterm trend in a desert riparian forest ecosystem on the eastern edge of the Taklimakan Desert in China. fournal of Hydrology 472: 90-98.

Hauck, M. (2010) Ammonium and nitrate tolerance in lichens. Environmental Pollution 158: 1127-1133.

Hauck, M., Jürgens, S. R., Brinkmann, M. \& Herminghaus, S. (2008) Surface hydrophobicity causes $\mathrm{SO}_{2}$ tolerance in lichens. Annals of Botany 101: 531-539.

Holien, H. (1996) Influence of site and stand factors on the distribution of crustose lichens of the Caliciales in a suboceanic spruce forest area in central Norway. Lichenologist 28: 315-330.

Jacobs, A. F. G., Heusinkveld, B. G. \& Berkowicz, S. M. (2002) A simple model for potential dewfall in an arid region. Atmospheric Research 64: 285-295.

Jacobs, A. F. G., Heusinkveld, B. G., Kruit, R. J. W. \& Berkowicz, S. M. (2006) Contribution of dew to the water budget of a grassland area in the Netherlands. Water Resources Research 42: W03415.

Johansson, O., Nordin, A., Olofsson, J. \& Palmqvist, K. (2010) Responses of epiphytic lichens to an experimental whole-tree nitrogen-deposition gradient. New Phytologist 188: 1075-1084.

Jonsson, A. V., Moen, J. \& Palmqvist, K. (2008) Predicting lichen hydration using biophysical models. Oecologia 156: 259-273.

Jonsson Čabrajič, A. V., Lidén, M., Lundmark, T., Ottosson-Löfvenius, M. \& Palmqvist, K. (2010) Modelling hydration and photosystem II activation in relation to in situ rain and humidity patterns: a tool to compare performance of rare and generalist epiphytic lichens. Plant Cell and Environment 33: 840-850.

Jørgensen, P. M. (1996) The oceanic element in the Scandinavian lichen flora revisited. Symbolae Botanicae Upsalienses 31: 297-317.

Kantvilas, G. \& Jarman, S. J. (1999) Lichens of Rainforest in Tasmania and South-eastern Australia. Canberra: The Australian Biological Resources Study.

Kappen, L. (1973) Response to extreme environments. In The Lichens (V. Ahmadjian, ed.): 311-380. New York: Academic Press.

Kappen, L., Lange, O. L., Schulze, E. D., Buschbom, U. \& Evenari, M. (1980) Ecophysiological investi- gations on lichens of the Negev desert. VII. The influence of the habitat exposure on dew imbibition and photosynthetic productivity. Flora 169: 216229.

Kershaw, K. A. (1985) Physiological Ecology of Lichens. Cambridge: Cambridge University Press.

Lakatos, M., Rascher, U. \& Büdel, B. (2006) Functional characteristics of corticolous lichens in the understory of a tropical lowland rain forest. New Phytologist 172: 679-695.

Lakatos, M., Obregón, A., Büdel, B. \& Bendix, J. (2012) Midday dew - an overlooked factor enhancing photosynthetic activity of corticolous epiphytes in a wet tropical rain forest. New Phytologist 194: 245-253.

Lang, S. I., Cornelissen, J. H. C., Hölzer, A., ter Braak, C. J. F., Ahrens, M., Callaghan, T. \& Aerts, R. (2009) Determinants of cryptogam composition and diversity in Sphagnum-dominated peatlands: the importance of temporal, spatial and functional scales. Fournal of Ecology 97: 299-310.

Lange, O. L. (2000) Photosynthetic performance of a gelatinous lichen under temperate habitat conditions: long-term monitoring of $\mathrm{CO}_{2}$ exchange of Collema cristatum. Bibliotheca Lichenologica 75: 307332.

Lange, O. L. (2003) Photosynthetic productivity of the epilithic lichen Lecanora muralis: long-term field monitoring of $\mathrm{CO}_{2}$ exchange and its physiological interpretation - III. Diel, seasonal, and annual carbon budgets. Flora 198: 277-292.

Lange, O. L. \& Kilian, E. (1985) Reaktiverung der Photosynthese trockener Flechten durch Wasserdampfaufnahme aus dem Luftraum: Artsspezifisch unterschiedliches Verhalten. Flora 176: 7-23.

Lange, O. L. \& Matthes, U. (1981) Moisture-dependent $\mathrm{CO}_{2}$ exchange of lichens. Photosynthetica 15: 555574 .

Lange, O. L. \& Redon, J. (1983) Epiphytische Flechten im Bereich einer chilenischen "Nebeloase" (Fray Jorge). II. Ökophysiologische Characterisierung von $\mathrm{CO}_{2}$-Gaswechesel und Wasserhaushalt. Flora 174: 2245-2284.

Lange, O. L., Schulze, E. D. \& Koch, W. (1970) Experimentell-ökologische Untersuchungen an Flechten der Negev-Wüste. II. $\mathrm{CO}_{2}$-Gaswechsel und Wasserhaushalt von Ramalina maciformis (Del.) Bory am natürlichen Standort während der sommerlichen Trockenperiode. Flora 159: 38-62.

Lange, O. L., Kilian, E. \& Ziegler, H. (1986) Water vapor uptake and photosynthesis in lichens: performance differences in species with green and bluegreen algae as phycobionts. Oecologia 71: 104-110.

Lange, O. L., Green, T. G. A. \& Ziegler, H. (1988) Water status related photosynthesis and carbon isotope discrimination in species of the lichen genus Pseudocyphellaria with green or blue-green photobionts and in photosymbiodemes. Oecologia 75: 494-501.

Lange, O. L., Bilger, W., Rimke, S. \& Schreiber, U. (1989) Chlorophyll fluorescence of lichens containing green and blue-green algae during hydration by water vapor uptake and by addition of liquid water. Botanica Acta 102: 306-313. 
Lange, O. L., Meyer, A., Zellner, H., Ullmann, I. \& Wessels, D. C. J. (1990) Eight days in the life of a desert lichen: water relations and photosynthesis of Teloschistes capensis in the coastal fog zone of the Namib desert. Madoqua 17: 17-30.

Lange, O. L., Büdel, B., Heber, U., Meyer, A., Zellner, H. \& Green, T. G. A. (1993a) Temperate rainforest lichens in New Zealand: high thallus water content can severely limit photosynthetic $\mathrm{CO}_{2}$ exchange. Oecologia 95: 303-313.

Lange, O. L., Büdel, B., Meyer, A. \& Kilian, E. (1993b) Further evidence that activation of net photosynthesis by dry cyanobacterial lichens requires liquid water. Lichenologist 25: 175-189.

Lange, O. L., Belnap, J. \& Reichenberger, H. (1998) Photosynthesis of the cyanobacterial soil-crust lichen Collema tenax from arid lands in southern Utah, USA: role of water content on light and temperature responses of $\mathrm{CO}_{2}$ exchange. Functional Ecology 12: 195-202.

Lange, O. L., Green, T. G. A. \& Heber, U. (2001) Hydration-dependent photosynthetic production of lichens: what do laboratory studies tell us about field performance? Fournal of Experimental Botany 52: 2033-2042.

Lange, O. L., Büdel, B., Meyer, A., Zellner, H. \& Zotz, G. (2004) Lichen carbon gain under tropical conditions: water relations and $\mathrm{CO}_{2}$ exchange of Lobariaceae species of a lower montane rainforest in Panama. Lichenologist 36: 329-342.

Lange, O. L., Green, T. G. A., Meyer, A. \& Zellner, H. (2007) Water relations and carbon dioxide exchange of epiphytic lichens in the Namib fog desert. Flora 202: $479-487$.

Larson, D. W. (1981) Differential wetting in some lichens and mosses: the role of morphology. Bryologist 84: 1-15.

Larson, D. W. \& Kershaw, K. A. (1976) Studies on lichen-dominated systems. XVIII. Morphological control of evaporation in lichens. Canadian fournal of Botany 54: 2061-2073.

Larsson, P., Solhaug, K. A. \& Gauslaa, Y. (2012) Seasonal partitioning of growth into biomass and area expansion in a cephalolichen and a cyanolichen of the old forest genus Lobaria. New Phytologist 194: 991-1000.

Lidén, M., Jonsson Cabrajic, A. V., Ottosson-Löfvenius, M., Palmqvist, K. \& Lundmark, T. (2010) Speciesspecific activation time-lags can explain habitat restrictions in hydrophilic lichens. Plant Cell and Environment 33: 851-862.

Lüdi, W. \& Zoller, H. (1953) Mikroklimatische Untersuchungen an einem Birnbaum. Berichte über das Geobotanische Forschunginstitut Rübel, Zürich 152: 103-128.

MacKenzie, T. B. D. \& Campbell, D. A. (2001) Evidence for wavelength-dependent light screening of cyanobionts and phycobionts in Lobaria during dehydration. Symbiosis 30: 57-70.

Máguas, C., Valladares, F. \& Brugnoli, E. (1997) Effects of thallus size on morphology and physiology of foliose lichens: new findings with a new approach. Symbiosis 23: 149-164.
Marini, L., Nascimbene, J. \& Nimis, P. L. (2011) Largescale patterns of epiphytic lichen species richness: photobiont-dependent response to climate and forest structure. Science of the Total Environment 409: 4381-4386.

McCune, B., Rosentreter, R., Ponzetti, J. M. \& Shaw, D. C. (2000) Epiphyte habitats in an old conifer forest in western Washington, U.S.A. Bryologist 103: 417-427.

Merinero, S., Hilmo, O. \& Gauslaa, Y. (2014) Size is a main driver for hydration traits in cyano- and cephalolichens of boreal rainforest canopies. Fungal Ecology in press.

Moen, A. (1999) National Atlas of Norway: Vegetation. Hønefoss: Norwegian Mapping Authority.

Motyka, J. (1947) Lichenum generis Usnea studium monographicum, pars generalis. Annales Universitatis Mariae Curie-Sklodowska, Lublin - Polonia, Sectio C 1(9): 277-476.

Nash, T. H. III, Reiner, A., Demmig-Adams, B., Kilian, E., Kaiser, W. M. \& Lange, O. L. (1990) The effect of atmospheric desiccation and osmotic water stress on photosynthesis and dark respiration of lichens. New Phytologist 116: 269-276.

Oke, T. R. (1987) Boundary Layer Climates. London: Routledge Taylor \& Francis Group.

Palmqvist, K. (2000) Carbon economy in lichens. New Phytologist 148: 11-36.

Pardow, A., Hartard, B. \& Lakatos, M. (2010) Morphological, photosynthetic and water relation traits underpin the contrasting success of two tropical lichen groups at the interior and edge of forest fragments. AoB Plants plq004. doi:10.1093/aobpla/ plq004.

Poorter, H. \& Remkes, C. (1990) Leaf-area ratio and net assimilation rate of 24 wild species differing in relative growth rate. Oecologia 83: 553-559.

Purvis, O. W., Dubbin, W., Chimonides, P. D., Jones, G. C. \& Read, H. (2008) The multi-element content of the lichen Parmelia sulcata, soil, and oak bark in relation to acidification and climate. Science of the Total Environment 390: 558-568.

Radies, D., Coxson, D., Johnson, C. \& Konwicki, K. (2009) Predicting canopy macrolichen diversity and abundance within old-growth inland temperate rainforests. Forest Ecology and Management 259: 86-97.

Redon, J. \& Lange, O. L. (1983) Epiphytische Flechten im Bereich einer chilenischen "Nebeloase" (Fray Jorge). I. Vegetationskundliche Gliederung und Standortsbedingungen. Flora 174: 213-243.

Reich, P. B., Ellsworth, D. S. \& Walters, M. B. (1998) Leaf structure (specific leaf area) modulates photosynthesis-nitrogen relations: evidence from within and across species and functional groups. Functional Ecology 12: 948-958.

Renhorn, K. E., Esseen, P. A., Palmqvist, K. \& Sundberg, B. (1997) Growth and vitality of epiphytic lichens I. Responses to microclimate along a forest edge-interior gradient. Oecologia 109: 1-9.

Richards, K. (2002) Hardware scale modelling of summertime patterns of urban dew and surface moisture in Vancouver, BC, Canada. Atmospheric Research 64: 313-321. 
Roe, G. H. (2005) Orographic precipitation. Annual Review of Earth and Planetary Sciences 645-671.

Rose, F. (1976) Lichenological indicators of age and environmental continuity in woodlands. In Lichenology: Progress and Problems (D. H. Brown, ed.): 279307. London: Academic Press.

Snelgar, W. P. \& Green, T. G. A. (1981) Ecologicallylinked variation in morphology, acetylene reduction, and water relation in Pseudocyphellaria dissimilis. New Phytologist 87: 403-411.

Stevenson, S., Armleder, H. M., Arsenault, A., Coxson, D., DeLong, S. C. \& Jull, M. (2011) British Columbia's Inland Rainforest. Ecology, Conservation, and Management. Vancouver: UBC Press.

Stoutjesdijk, P. (1974) The open shade, an interesting microclimate. Acta Botanica Neerlandica 23: 125130.

Stoutjesdijk, P. \& Barkman, J. J. (1987) Microclimate. Vegetation and Climate. Knivstad, Sweden: Opulus Press AB.

Tønsberg, T., Gauslaa, Y., Haugan, R., Holien, H. \& Timdal, E. (1996) The threatened macrolichens of Norway - 1995. Sommerfeltia 23: 1-283. van Herk, C. M., Mathijssen-Spiekman, E. A. M. \& de Zwart, D. (2003) Long distance nitrogen air pollution effects on lichens in Europe. Lichenologist 35: 347-359.

Walker, M. D., Wahren, C. H., Hollister, R. D., Henry, G. H. R., Ahlquist, L. E., Alatalo, J. M., Bret-Harte, M. S., Calef, M. P., Callaghan, T. V., Carroll, A. B., et al. (2006) Plant community responses to experimental warming across the tundra biome. Proceedings of the National Academy of Sciences of the United States of America 103: 1342-1346.

Walter, H. \& Breckle, S. W. (1984) Ökologie der Erde. Stuttgart: Gustav Fischer Verlag.

Wright, I. J., Groom, P. K., Lamont, B. B., Poot, P., Prior, L. D., Reich, P. B., Schulze, E. D., Veneklaas, E. J. \& Westoby, M. (2004) Leaf trait relationships in Australian plant species. Functional Plant Biology 31: 551-558.

Xiao, H., Meissner, R., Seeger, J., Rupp, H., Borg, H. \& Zhang, Y. (2013) Analysis of the effect of meteorological factors on dewfall. Science of the Total Environment 452-453: 384-393. 